\title{
„Nazbyt literackie”. \\ Związki między Akutagawą Ryūnosuke i Tanizakim Jun'ichirō
}

DOI: http://dx.doi.org/10.12775/LC.2017.061

Streszczenie: Tematem artykułu są relacje między dwu wybitnymi pisarzami japońskimi z wyróżnieniem epizodu ich spotkania w Osace w ostatnim roku życia Akutagawy oraz ich polemiki na temat istoty powieści.

Autor artykułu wyjaśnia istotę tej polemiki, którą zapoczątkowała krytyczna wobec Tanizakiego wypowiedź Akutagawy w dyskusji publikowanej na łamach „Shinchō”. Natomiast Tanizaki w cyklu esejów Jözetsuroku (Kronika gadulstwa) wyjaśnial, że struktura fabularna powieści podnosi jej wartość artystyczną. Dla Akutagawy była to też okazja do krytycznej oceny współczesnych mu zjawisk literackich. Sformułował je w 50 esejach pt. Literackie, nazbyt literackie.

W tym artykule autor koncentruje się na analizie esejów, w których Akutagawa ocenia między innymi twórczość takich pisarzy, jak: Shiga Naoya, Satō Haruo, Natsume Sōseki, Masamune Hakuchō, Tokuda Shūsei, Mori Ōgai i wielu innych, między innymi autorów tak zwanej powieści popularnej.

Jednak najczęściej przypominanym wątkiem wspomnianych esejów jest polemika, która zainteresowała czytelników dzięki śmiałym ocenom, między innymi pochwale powieści popularnej przez Tanizakiego, który skrytykował powieść autobiograficzną, ponieważ w tym czasie interesowały go bardziej „zmyślenia” niż opis przeżyć pisarza. Natomiast Akutagawa bronił prawdy o życiu wewnętrznym pisarza jako krytyka cywilizacji.

Kontrowersje między Akutagawą a Tanizakim zainteresowały środowisko literackie nie tylko ze względu na nazwiska cenionych pisarzy, lecz także z powodu oczekiwań odważnych opinii na temat dominującej wówczas formy literackiej, jaką stała się powieść, lecz także sytuacji w życiu kulturalnym kraju. Przedwczesna śmierć Akutagawy głęboko poruszyła czytelników i nadała polemice nowe znaczenia. Stała się ważnym wyznacznikiem zakończenia się okresu Taishō, mimo że toczyła się na marginesie życia społecznego i politycznego, obfitującego w symptomy niepokoju o przyszłość kraju. Polemika miała więc charakter po prostu literacki, nazbyt literacki - jak to określił Akutagawa.

\footnotetext{
Profesor dr hab., prof. emerytowany Uniwersytetu Warszawskiego, wykłada w Katedrze Japonistyki. Badacz literatury i kultury Japonii, autor licznych przekładów. E-mail: m.melanowicz@uw.edu.pl.
} 
Słowa kluczowe: Akutagawa Ryūnosuke, Tanizaki Jun'ichirō, spotkania, Bungeiteki na, amari ni bungeiteki na (Literackie, nazbyt literackie), Jōzetsuroku (Kronika gadulstwa), Nezu Matsuko

\title{
„Overly literary”. \\ Relations between Akutagawa Ryūnosuke and Tanizaki Jun'ichirō
}

\begin{abstract}
The subjects of the article are the relations between two renowned Japanese writers with focus on their encounter in Osaka in the final year of Akutagawa and their dispute about the essence of a novel.

The author of the article explains the point of the dispute which started after criticism of Tanizaki expressed by Akutagawa in a discussion published in Shinchō. In a series of essays titled Jozzetsuroku (Garrulous Notes) Tanizaki claimed that a plot-based structure of a novel improves its artistic value. For Akutagawa it was an opportunity to voice criticism about contemporary literary trends. He composed 50 essays titled Literary, Overly Literary.

In this article the author focuses on the analysis of essays in which Akutagawa judges the works of writers such as: Shiga Naoya, Satō Haruo, Natsume Sōseki, Masamune Hakuchō, Tokuda Shūsei, Mori Ōgai and many others, e.g. authors of the so-called popular literature.

Nonetheless, the most popular theme in the essays is the above-mentioned dispute which appealed to readers with its bold statements, e.g. praise of popular literature by Tanizaki who berated autobiographical novels as at the time he was more interested in "fiction" than in descriptions of the experience of writers. Akutagawa, in turn, defended the truth about the inner life of writers as critics of civilisation.

The literary circles were curious about the controversies between Akutagawa and Tanizaki because the two were highly esteemed writers and people wanted to hear bold opinions about the novel - the prevailing genre at the time, and about the condition of the cultural life in the country. The premature death of Akutagawa deeply moved the readers and gave the dispute a new meaning. It marked the end of the Taisho period even though it happened in the background of the social and political life abundant with symptoms of concern about the future of the country. Hence the dispute had a literary, overly literary nature, as Akutagawa put it.
\end{abstract}

Keywords: Akutagawa Ryūnosuke, Tanizaki Jun'ichirō, encounters, Bungeiteki na, amari ni bungeiteki na (Literary, Overly Literary), Jōzetsuroku (Garrulous Notes), Nezu Matsuko

\section{Wstęp}

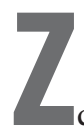

dawałoby się, że Akutagawę i Tanizakiego, bohaterów tego artykułu, wszystko różniło. I przynależność pokoleniowa, i usytuowanie w podręcznikach literatury. A jednak coś ich łączy. I o tym będzie mowa w tym artykule. Po pierwsze, o pamiętnym spotkaniu w Osace w ostatnim roku życia Akutagawy, a po drugie, o ich polemice na temat istoty powieści, 
która pozwoliła oceniać życie literackie Taishō, okresu, w którym - po śmierci Natsume Sōsekiego - pojawili się dwaj wybitni twórcy, mianowicie: wcześniej Tanizaki Jun’ichirō (1886-1965), a później Akutagawa Ryūnosuke (1892-1927).

Akutagawa, poczynając od debiutu prasowego w 1914 roku, unikał pisania o sobie, mimo panującej wówczas mody na wyznania osobiste naturalistów. Po prostu kreował fikcyjny świat opowieści, czerpiąc motywy z klasyki rodzimej, chińskiej i zachodnio-europejskiej. Kreował więc fikcyjną rzeczywistość. Był wtedy przeciwnikiem naturalizmu i tak zwanych powieści o sobie. Nie akceptował też idealizmu Szkoły Białej Brzozy. Chętniej sięgał po wzory wielkich twórców europejskich, a zwłaszcza wyrazicieli dekadencji, których uwiecznił w Życiu pewnego szaleńca ${ }^{1}$. Wyznawał koncepcję sztuki dla sztuki, a w akcie tworzenia dostrzegał wartości moralne, analizował też sprzeczności między dobrem i złem w życiu bohaterów opowiadań.

Jednak po trzęsieniu ziemi w 1923 roku uległ nastrojom kryzysowym, czuł się wyczerpany i rozczarowany. Nie wiodło mu się w życiu rodzinnym. I od tego też czasu zmieniła się jego twórczość, to znaczy tematyka i styl pisania. Publikował opowiadania realistyczne, w znacznym stopniu o wątkach autobiograficznych, poczynając od Yasukichi no techō kara (Z notatnika Yasukichiego, 1923), Ikkai no tsuchi (Gruda ziemi, 1924) aż po Tenkibo (Rejestr umarlych, 1926) oraz pośmiertną krótką powieść Kappy $(1927)^{2}$, szkice Życie szaleńca (1927) i opowiadanie Haguruma (Zębate koła, 1927).

W latach 1925-1926 przezwyciężył kryzys. Świadczyć o tym mógł utwór Koshibito (Osoba z Koshiji), ułożony ze strof starożytnej formy poetyckiej sedōka, to znaczy poemat o mężczyźnie, który pragnie porzucić rodzinę dla miłości ${ }^{3}$. Wtedy był zakochany w poetce Matsumurze, czytał wyznania Goethego i Shigi Naoi i zaczął pisać o swych uczuciach, o niepokojach i lękach. W tym czasie poszukiwał nowych środków wyrazu, baczniej obserwując rozwój literatury współczesnej. Na pewno niepokoiły go gry generałów, więc obawiał się o przyszłość swego kraju. I wtedy też skoncentrował się na krytyce literackiej, dla której silnym bodźcem była dyskusja z Tanizakim na temat ważnych kwestii w okresie zmiany swej filozofii życia i jej ekspresji.

Tanizaki również w latach 1925-1927 zastanawiał się nad sposobem pisania o nowych problemach po zmianie środowiska - po przeprowadzce z Kantō do Kansai. Zaczął interesować się dawną formą prozy japońskiej, a przede wszystkim opowieścią monogatari. Był przekonany, że również powieść współczesna powinna mieć formę opowieści fikcyjnej, a nie zwyczajnym opisem rzeczywistości. Odniósł sukces, publikując modernistyczną Chijin no ai (Miłość szaleńca, 1924), a następnie Manji (W wirach namiętności, 1928, 1931) i Tade kuu mushi (Niektórzy wola pokrzywy, 1929). W tym ważnym okresie zmian w życiu pisarzy i kształtowania się nowych poglądów na funkcję prozy literackiej doszło do spotka-

\footnotetext{
1 „Było to na piętrze pewnej księgarni. Dwudziestolatek wszedł na drabinkę w europejskim stylu, opartą o półki i szukał nowych książek. Maupassant, Baudelaire, Strindberg, Ibsen, Shaw, Tołstoj... Tymczasem zbliżał się zmierzch. Lecz on nadal namiętnie odczytywał litery na grzbietach książek. Stały tutaj bowiem nie tyle książki, ile raczej sam koniec wieku: Nietzsche, Verlaine, bracia Goncourt, Dostojewski, Hauptman, Flaubert...." Zob. R. Akutagawa, Życie pewnego szaleńca (1. Epoka), tłum. M. Melanowicz, [w:] idem, Życie szaleńca i inne opowiadania, Warszawa 1998, s. 143.

2 R. Akutagawa, Kappy, tłum. M. Melanowicz, Warszawa 1963.

3 W tym czasie Akutagawa spotkał poetkę Katayamę Hiroko (inne jej nazwisko to Matsumura Miyoko, 1878-1957) w Karuizawie. Nie ma pewności, w jakim stopniu utwór Koshibito, publikowany pod nazwiskiem Akutagawy na łamach "Myōjō" (marzec 1925), był jego autorstwa, więc w późniejszych dziełach zebranych nie pojawia się. Nie ma jednak wątpliwości, że poemat ten wyraża uwielbienie dla poetki Katayamy (Matsumury).
} 
nia Akutagawy z Tanizakim w Kansai, które odegrało dużą rolę w życiu i literackiej aktywności obu mężczyzn. Dlatego w tym artykule poświęcę znacznie więcej uwagi osobistym sprawom pisarzy, niż czyniłem to przed dziesiątkami lat, gdy pod wpływem strukturalizmu zajmowałem się przede wszystkim twórczością Tanizakiego, a następnie Akutagawy. Można bowiem przypuszczać, że to spotkanie dało im impuls do wyjątkowo intensywnej aktywności krytycznej. A jej rezultatem są dwa cenione zbiory esejów, a mianowicie Jōzetsuroku (Kronika gadulstwa, 1927) Tanizakiego i Bungeiteki na, amari ni bungeiteki na (Literackie, nazbyt literackie, 1927) Akutagawy, w którym najważniejszym wątkiem była polemika między pisarzami.

\section{Spotkania}

Spotkanie w Osace w 1927 roku było wyjątkowo ważne zarówno dla Akutagawy, jak i Tanizakiego, chociaż wcześniej, przed trzęsieniem ziemi w Tokio i Jokohamie w 1923 roku, spotykali się wielokrotnie. Akutagawa wspomina ${ }^{4}$ spotkanie w kawiarni w okolicy Kandy w Tokio wczesnym latem. Wówczas Tanizaki pojawił się w czarnym garniturze z „czerwoną ozdobą przy kołnierzu” (erikazari), a kelnerka, która przyniosła zamówioną wodę sodową, pochwaliła go, mówiąc: „»Och, jaki ładny ma pan krawat«. W ten sposób nie tylko przyniosła mi wodę sodową, lecz także ogłosiła światu prawdę o czerwonej ozdobie przy kołnierzu"5 - pisał Akutagawa, który zamierzał dać 10 senów jako napiwek, ale obawiał się, że Tanizaki potraktowałby go pogardliwie za ten niepotrzebny gest. Nie zanotował, o czym rozmawiali wtedy, gdy wpadli na dziesięć minut do kawiarni w dzielnicy księgarń Jinbō, ale wiadomo, że krawat Tanizakiego wprawił go w romantyczny nastrój. Ich bliskie stosunki przerwało trzęsienie ziemi i przeprowadzka Tanizakiego do Kansai.

Tanizaki również pisał o związkach z Akutagawą w eseju na łamach „Kaizō” we wrześniu $1927 \mathrm{roku}^{6}$. A mianowicie o ich związkach świadczyć miało to samo miejsce urodzenia w centrum Tokio: Akutagawa w Irifune, w dzisiejszej dzielnicy Chūō, a Tanizaki w Kakigara w Nihonbashi. W cytowanym wspomnieniu czytamy też o wspólnej w zasadzie edukacji w szkole średniej i licealnej oraz o tej samej uczelni - Cesarskim Uniwersytecie Tokijskim. Poza tym obaj debiutowali w czasopiśmie „Shinshichō” - Tanizaki w drugim wydaniu periodyku dramatem Tanjō (Narodziny, 1910), którego akcja toczy się w czasach Fujiwary Michinagi. Natomiast Akutagawa - w trzecim wznowieniu tego pisma opublikował opowiadanie Rashōmon (Brama Demonów, 1917), również oparte na motywach z epoki Heian. Zatem obaj interesowali się klasyką wschodnią - rodzimą i chińską. Poza tym Akutagawa zmarł w dniu, w którym Tanizaki się urodził: 24 lipca 1927, natomiast Tanizaki urodził się 24 lipca 1886 roku. Poza tym ich przodkowie uczęszczali do tych samych świątyń. Dopiero gdy Akutagawa odwiedził czytelników w Osace w 1927 roku, doszło do odnowienia stosunków, chociaż nie na długo. Jednak było darem niebios przede wszystkim dla Tanizakiego. Nie

\footnotetext{
${ }^{4}$ R. Akutagawa, Tanizaki Jun'ichirō shi, [w:] Akutagawa Ryūnosuke zenshū (Dzieła zebrane Akutagawy), t. 10, Tōkyō 1996. Publikacja dostępna na stronie Aozora Bunko, http://www.aozora.gr.jp [dostęp: 10.08.2016].

5 Ibidem.

6 J. Tanizaki, Akutagawa kun to watakushi, [w:] Akutagawa Ryūnosuke annai (Przewodnik AR), red. S. Nakamura, Tōkyō 1955, s.119-120.
} 
było też obojętne dla Akutagawy, ponieważ skłoniło go do niezwykle aktywnej pracy krytycznej, zarówno wywołanej koniecznością odpowiedzi na zarzuty ze strony Tanizakiego, jak i na duchową potrzebę spowiedzi literackiej, oczekiwanej przez czytelników od swych ulubionych autorów.

\section{Akutagawa w Osace}

Akutagawa spotkał się z Tanizakim w restauracji (ochaya) znajdującej się w Nanchi, wówczas modnej dzielnicy gejsz, w której często bywał Nezu Seitarō, znany właściciel hurtowni bawełny. Jego żona Matsuko poprosiła gospodynię restauracji o umożliwienie spotkania z jej ulubionym pisarzem. Gdy weszła do salonu, w którym Akutagawa delektował się sake, okazało się, że towarzyszył mu inny mężczyzna. Był nim Tanizaki. Jej uroda, nienaganne ruchy podającej sake i zakąski oczarowały Jun’ichirō. Od tego wieczoru Matsuko stała się dla niego boginią literatury. A kiedy zamieszkał w hotelu pracowniczym przedsiębiorstwa Nezu (wtedy jeszcze nie miał stałego mieszkania), mógł przebywać w sąsiedztwie jego żony. Potem zmieniał miejsce zamieszkania, żeby być jej sąsiadem.

W tym czasie, to znaczy w końcu lat dwudziestych, Tanizaki miał żonę Tomiko, która towarzyszyła mu podczas spotkań z Matsuko, jeszcze mężatką, ale opuszczoną przez męża, który podobno uciekł z jej siostrą, więc Matsuko czuła się bardzo samotna, chociaż miała przy sobie córkę (jej syn pozostał pod opieką ojca Nezu). Odwiedzały ją jej dwie siostry, które Tanizaki dobrze poznał, a poźniej mógł je uczynić modelkami sióstr Makioka, bohaterek powieści Sasameyuki (Drobny śnieg, 1948). To w tym okresie Tanizaki codziennie pisał listy do Matsuko ${ }^{7}$.

Warto pamiętać, że Matsuko - druga córka Mority Anshō (1864-1926), dyrektora korporacji stoczniowej - miała trzy siostry. W 1934 roku rozwiodła się z Nezu i wyszła za mąż za Jun'ichirō, który wcześniej uporządkował swoje skomplikowane sprawy osobiste („przekazanie” pierwszej żony Chiyoko swemu koledze, pisarzowi Satō Haruo ${ }^{8}$, poślubienie i rozwód z Tomiko). Tanizaki uwielbiał Matsuko, która wywarła wielki wpływ na jego twórczość, zwłaszcza na takie arcydzieła, jak Shunkinshō ${ }^{9}$ i Sasameyuki $i^{10}$.

Spotkanie w Osace umożliwiło głębsze poznanie poglądów Tanizakiego, z którym rozpoczął polemikę na łamach wpływowego miesięcznika „Kaizō” ku zadowoleniu czytelników. A poza tym - zachęcony przez Tanizakiego - obejrzał przedstawienie sztuki Kamiya Jihei i Koharu, to znaczy popularną wersję Shinjū ten no Amijima (Samobójstwo kochanków w niebiańskiej Amijimie, 1721) w teatrze lalkowym, o czym później pisal, jakby kontynuując nocne rozmowy w restauracji w Nanchi, jak również w taksówce, w drodze powrotnej z teatru.

7 W 2014 roku spadkobiercy udostępnili wydawcy 288 listów Jun'ichirō pisanych w latach 1927-1963 do Matsuko i jej sióstr. Listy zostały opublikowane w 1915 roku przez Chūō Kōronsha.

8 Incydent ten Tanizaki wykorzystał w powieści Niektórzy wolą pokrzywy, w której kochankiem żony bohatera Kaname jest poeta Satō Haruo pod nazwiskiem Aso.

9 Zob. J. Tanizaki, Shunkinshō, czyli Rozmyślania nad życiem Wiosennej Harfy, tłum. M. Melanowicz, [w:] idem, Dwie opowieści o miłości okrutnej, Warszawa 1971.

10 Na temat bohaterek wzorowanych na córkach Mority zob. M. Melanowicz, Śnieg i wiśnia - semiotyka tytułu wobec świata przedstawionego w powieści „Sasameyuyki” Jun'ichirō Tanizakiego, [w:] idem, Japońskie narracje. Studia o pisarzach współczesnych, Kraków 2004. 
Po pamiętnym spotkaniu w Osace rozpoczęła się wymiana poglądów między obu pisarzami, zwana polemiką (ronsō), publikowaną na łamach „Kaizō” od lutego do lipca $1927 \mathrm{roku}^{11}$.

\section{Akutagawa jako krytyk literatury okresów Meiji i Taishō}

W 50 esejach Bungeiteki na... Akutagawa opisuje i ocenia sytuację w japońskiej literaturze współczesnej. Rozpoczyna również polemikę z Tanizakim, której głównym przedmiotem był problem roli anegdoty, rozumianej jako schemat zdarzeniowy utworu literackiego. Należy wspomnieć, że w odróżnieniu od Akutagawy Tanizaki przywiązywał wagę do ciągu i wzajemnego powiązania zdarzeń w powieści.

W pierwszym eseju Akutagawa pisał: „Nie uważam, że najlepsze są powieści bez prawdziwych opowiadań (hanashirashi hanashi no nai shōsetsu). Dlatego nie mówię, żebyś pisał tylko powieści bez zdarzeń"12. Następnie dodaje, że takie powieści bliskie poezji jednak istnieją. I należą one do tak zwanych powieści czystych (junsui shōsetsu). Porównuje je do kolorystycznych kompozycji malarskich, pozbawionych deseni, jakimi są na przykład niektóre obrazy Paula Cezanne’a. A w drugim eseju Odpowiadam panu Tanizakiemu nie zgadza się $\mathrm{z}$ twierdzeniem, że to powieść w największym stopniu cechuje piękno struktury (kōzōteki bikan), i daje przykłady wierszy haiku i dramatu. I tak rozpoczyna się ta polemika jako jeden z wątków oceny sytuacji w świecie literackim Japonii, dokonywanej przez Akutagawę.

\section{Shiga Naoya wzorem „czystej literatury”}

W kilku esejach (piątym, szóstym) Akutagawa twierdzi, że najbardziej „czystą” (mottomo junsui na sakka) twórczość reprezentuje Shiga Naoya (1883-1971). Następnie, powołując się na Satō Haruo (1892-1964), przypomina, że współcześni literaci posługują się stylem mówionym (kōgobun), a więc takim językiem, jakim Japończycy mówią codziennie. Niewątpliwie sam chciałby pisać tak jak mówi, ale też chciałby mówić tak jak pisze. To mistrz Natsume Sōseki (1867-1916) był pisarzem, który mówił tak jak pisał. Przy tej okazji wspomina termin shaseibun (styl szkicowania z natury), modny za czasów Natsumego, wyjaśniany przez poetę haiku Takahamę Kyoshiego (1874-1959). A w następnym eseju Proza poetów przywołuje Oku no hosomichi (Ścieżki na Daleką Pólnoc, 1684) Matsuo Bashō (1644-1694).

Autor Rashōmona dostrzega bohaterów moralnych i czystych w twórczości Shigi, który w opisie ich świata nie zmyśla, lecz po prostu zachowuje wierność rzeczywistości (tę uwagę kieruje przede wszystkim do Tanizakiego). W jego realizmie kryje się bowiem duch

11 Zob. R. Akutagawa, Bungeiteki na, amari ni bungeiteki na, [w:] Akutagawa Ryūnosuke zenshū, t. 12, Tōkyō 1955, s.109-183. Tanizaki publikował w cyklu esejów Jōzetsuroku (Kronika gadulstwa, 1927).

12 Ibidem, s. 109. 
poetycki, wyrastający z tradycji orientalnej. Jego utwory, takie jak Takibi (Ognisko, 1920) czy Manazuru (nazwa geograficzna, 1920) mają specyficzną barwę. Akutagawa docenia też jego technikę pisarską, której wysoki poziom dostrzega w An'ya kōro (Droga w mrokach nocy, 1921).

\section{Kitahara Hakushū i inni poeci}

Na prozę japońską wpływ miała również poezja Omoide (Wspomnienia, 1911) Kitahary Hakushū (1885-1942), jak również poety Kinoshity Mokutarō (1885-1945) - twierdzi Akutagawa na poparcie swej tezy o „duchu poetyckim” powieści. Przywołuje też wkład tradycyjnej formy krótkiej pieśni poety Ishikawy Takuboku (1886-1912) czy Yoshii Isamu (1886-1960), Masaoki Shikiego (1867-1902) i Saitō Mokichiego (1882-1953).

\section{Różnice i podobieństwa między Tanizakim i Akutagawą}

W toku tej polemiki Tanizaki występował przeciw powieści typowej dla późnych naturalistów posługujących się głównie opisem i narracją w utworach zbudowanych często z dość luźnych szkiców z życia osobistego pisarza i jego otoczenia. Nie atakował Akutagawy, gdyż nie miał powodów. Akutagawa bowiem - podobnie jak Tanizaki - często czerpał materiał z dokumentów i rodzimych dzieł klasycznych. Pisał również opowiadania, w których fabuła odgrywała ważną rolę. Natomiast kilka lat przed śmiercią, wyczerpany fizycznie i psychicznie, pisał szkice autobiograficzne, takie jak Tenkibo (Rejestr zmarlych, 1926), Shinkirō (Miraż, 1927) i Aru ahō no isshō (Życie pewnego szaleńca, 1927). Obchodziła go wtedy bardziej prawda o życiu wewnętrznym pisarza, skonfrontowanym $\mathrm{z}$ otaczającym go światem. Interesował się powołaniem pisarza jako krytyka cywilizacji i nie przywiązywał wagi do komponowania „normalnej” powieści fabularnej.

Podczas tej polemiki Tanizaki nie mógł znać krótkiej powieści Kappy (inny polski tytuł: $W$ krainie wodników) ani szkiców Życie pewnego szaleńca, ponieważ te utwory ukazały się pośmiertnie, jednak czytał wcześniejsze publikacje Akutagawy, znał więc zmiany, jakie zaszły w treści i formie późnej twórczości, poglądy na literaturę, a zwłaszcza jego krytyczny stosunek do naturalizmu.

\section{Naturaliści: Masamune Hakuchō i Tokuda Shūsei}

Jednak Akutagawa cenił niektóre utwory wybitnych naturalistów (między innymi esej dziewiąty), zwłaszcza Tokudy (1871-1943) i Masamunego (1879-1962) jako pisarzy najbardziej obiektywnych spośród naturalistów, ukazujących mroczny świat współczesnej Japonii. A pesymizm Masamunego przeciwstawiał optymizmowi idealisty Mushanokōjiego

Saneatsu (1885-1976). Stwierdził, że szkice o Dantem Masamunego nie są gorsze od rozważań Benedetto Crocego (esej dwudziesty pierwszy). Poza tym dr Ueda Bin (1874- 
$-1916)^{13}$ również studiował twórczość Dantego, próbował nawet tłumaczyć Boską komedię z języka angielskiego na japoński.

Następnie Akutagawa koncentruje się na problemie pesymizmu i twierdzi, że według Masamunego życie jest zawsze mroczne. Wierzył bowiem, że człowiekowi trudno się uratować przed cierpieniem, niezależnie od przynależności do organizacji społecznej (esej dziesiąty). Zwraca też uwagę na różnice, jakie zachodzą między twórczością Masamunego a pisarzami proletariackimi lat dwudziestych.

\section{Twórcy na poły zapomniani I INNI}

Akutagawa pisze też o średniowiecznych poetach zapomnianych, takich jak awanturnik François Villon czy siogun Minamoto Sanetomo (1192-1219), którzy przegrali w życiu, ale być może odnieśli sukces artystyczny. Wspomina też takich, którzy urodzili się za wcześnie lub za późno.

Duch poetycki

Gdy w czasie spotkania w 1927 roku Tanizaki zapytał, co znaczy „duch poetycki” (esej dwunasty), Akutagawa odpowiedział, że jest to poezja liryczna w najszerszym rozumieniu tego określenia. Zapytał też, czy wobec tego ten „duch” może być we wszystkich utworach. Nie zaprzeczył i dodał, że „duch poetycki” znajduje się i w Madame Bovary, Hamlecie, w Boskiej komedii, a nawet w Podróżach Guliwera. To zależy od geniuszu twórcy decydującym o jakości dzieła.

\section{Mori Ōgai}

Akutagawa wspomina, że w tym czasie czytał szósty tom Dzieł zebranych Moriego (1862-1922), podziwiając wiedzę i harmonijność jego powieści i dramatów. Według niego japoński neoromantyzm zrodził niewiele utworów tak doskonałych jak na przykład dramat Ikutagawa (Rzeka Ikuta, 1910). Ale jego wiersze tanka czy haiku tego poziomu nie siegają. Mori był raczej poetą (shijin) nowoczesnym. Poza tym na pewno nie cierpiał na rozstrój nerwowy tak jak on (Akutagawa) i jego pokolenie.

Shirayanagi Shūko

W czternastym eseju Akutagawa wspomina zbiór szkiców, zwłaszcza na temat estetyki i etyki pt. Koe naki ni kiku (Pytam bez głosu) Shirayanagiego Shūko (1884-1950), które miały wpływ na kształtowanie się jego poglądów.

\section{Natsume Sōseki}

Natsume Sōsekiego (esej siedemnasty) nazywa mistrzem (sensei), podobnie jak Moriego Ōgaia, nie mając wątpliwości, że to namiętność mistrza zrodziła takie utwory, jak Sorekara (Następnie, 1909), Mon (Wrota, 1910), Kōjin (Wędrowcy, 1912-1914), Michikusa (Trawa przydrożna, 1915), odnotowuje też wrażenia, jakie miał w czasie czytania listów Mérimée (Merime shotanshū, esej osiemnasty).

\footnotetext{
13 Akutagawa podaje stopień naukowy Uedy, poety i tłumacza.
} 
Tanizaki i Chikamatsu Monzaemon

W eseju dwudziestym drugim pt. Chikamatsu Monazaemon wspomina chwile, jakie spędził z Tanizakim i Satō Haruo, oglądając sztukę na temat Koharu i Jiheia. Snuje też rozważania nad Chikamatsu (1653-1724), który w odróżnieniu od realisty Ihary Saikaku (1642-1693) był pewnie idealistą. Co prawda, nie znał poglądów na życie tego dramatopisarza, ale oglądając jego sztuki jōruri, nie mógł stwierdzić, że był idealistą, ale odniósł wrażenie, że był raczej romantykiem.

\section{Senryū}

Przy okazji rozważań o literaturze epoki Edo Akutagawa pisze również o senryū jako japońskiej poezji satyrycznej (esej dwudziesty piąty), jak też o drzemiących formach poetyckich, takich jak Heike monogatari (Opowieść o rodzie Taira, ok. 1220), yōkyoku (dramat nō), jōruri (dramat teatru lalkowego).

\section{Literatura proletariacka i Kunikida Doppo}

O literaturze proletariackiej Akutagawa pisze jako o sztuce walczącej na rzecz proletariatu. Następnie (esej dwudziesty ósmy) polemizuje z krytyką pisarstwa Kunikidy Doppo (1871-1908) twierdząc, że Kunikida jest pisarzem o przenikliwym umyśle i łagodnym sercu. Był jednak postacią tragiczną, podobnie jak Futabatei Shimei (1864-1909) i Ishikawa Takuboku (1886-1912). Był też poetą różniącym się od Shimazakiego Tōsona (1872-1943) i Tayamy Kataia (1871-1930). Jest autorem takich cenionych opowiadań jak Shōjikimono (Uczciwy człowiek, 1903) i Take no kido (Bambusowa furtka, 1908), jak również Hibon naru bonjin (Niezwyczajny zwykły człowiek, 1906) i Shōnen no hiai (Smutki chłopca, 1902). Dlatego cenili go zarówno naturaliści, jak i humaniści Szkoły Białej Brzozy.

ZNÓW ODPOWIADA TANIZAKIEMU i wraca do spraw ogólniejszych W eseju dwudziestym dziewiątym Znów odpowiadam panu Tanizakiemu Akutagawa nawiązuje do lektury Jōzetsuroku (Kronika gadulstwa, 1927) i wyjaśnia, że nie tylko do niego kieruje swą odpowiedź, jednak okazuje się, że polemizować może tylko z nim, formułując swoje wyjaśnienia w czterech punktach.

1. Nawiązuje do wcześniejszej dyskusji na temat powieści niefabularnej. Wyjaśnia też takie problemy jak „czystość” czy „poetycki duch”, których Tanizaki nie rozumiał.

2. Pisze, że teraz zrozumiał, co znaczy „siła kompozycji” (kōsei suru chikara) i nie neguje zarzutu, że takiej cechy brakuje dzisiejszej sztuce literackiej. Ale jeśli widzi ją Tanizaki tylko w powieści, to jest problem, ponieważ są inne formy, w których ta cecha jest również ważna.

3. Zgadza się z uwagą Tanizakiego, że wielkość Goethego polega na „czystości” (junsuisei), mimo wielkiej skali jego dzieł i braku spójności (zappaku na), jak określił Akutagawa Goethego, ale Tanizaki to określenie pewnie potraktował jako negatywne.

4. W tym punkcie Akutagawa notuje kilka uwag dotyczących twierdzenia Tanizakiego o tym, że obaj się różnią charakterem. Niewątpliwie Tanizaki kocha Murasaki Shikibu, która w dzienniku określa Sei Shōnagon raczej złośliwie. Czy to świadczy o różnicy ich charakterów? Można to zrozumieć raczej jako potępienie krytyka, podobnie jak rywalki przez Murasaki Shikibu. Należy też odnotować, że 
Akutagawa przypomniał sobie, jak minionego roku nocą w taksówce Tanizaki prowadził dla niego wykład na temat sztuki.

Głos dzikości

W eseju trzydziestym zatytułowanym Głos dzikości wspomina, jak oglądał Kobiety z Tahiti Paula Gauguina na wystawie zorganizowanej przez towarzystwo artystyczne Kōfukai (założone w 1912 roku). W kobiecie z Tahiti dostrzegł wtedy ludzką bestię barwy pomarańczowej. Z kolei pewien krytyk literacki miarą oceny powieści na przykład Masamunego czynił opis ludzkiej bestii, to znaczy zastanawiał się, czy pisarz przedstawił człowieka jako bestię, czy też nie. Inny znowu krytyk twierdził, że Tanizaki miarą oceny dzieła czyni piękno malarskie przedstawiające bestię ludzką (ludzkie zwierzę).

W następnym eseju pt. Głos wołający z Zachodu pisze, że kobiety Gauguina wydają głos dzikości. Natomiast od Młodego Buddy Odilona Redona Akutagawa słyszy wołanie z Zachodu, które nie wiadomo dokąd go prowadzi.

Epoka krytyki

Akutagawę zainteresowała krytyka uprawiana przez powieściopisarzy. Chwali między innymi artykuł O Dantem czy Krytykę literacką Masamunego, jak również eseje Satō Haruo z „Chūō Kōron” (maj) i Miyake Ikusaburō (1897-1941) z „Bungei Jidai” (maj). Satō twierdzi, że współcześni pisarze są zmęczeni, a tylko Akutagawa nie jest. Twierdzi, że japoński Parnas jest ograniczony konwencjami.

Shinkankakuha, czyli szkoła sensualistyczna

Kiedy Akutagawa zaczynał publikować, jego twórczość nazywano neointelektualną (shinrichiha), ale on tej nazwy nie używał - pisze w eseju trzydziestym trzecim. A teraz utwory kilku młodych pisarzy, publikowane po 1923 roku, zaliczono do szkoły shinkankakuha. Są one bliskie dawnej prozie Akutagawy. Niewątpliwie, te utwory są nowsze od Akutagawy czy Murō Saiseia, ale są bliskie neointelektualizmowi. Głównym przedstawicielem neosensualizmu jest Yokomitsu Riichi (1898-1947), który wyjaśniał Akutagawie, na czym polega nowa wrażliwość (sensualizm), dając przykład wypowiedzianego przez Fujisawę Takeo (1910-1988) zdania brzmiącego tak: „Koń pobiegł jak brązowa mýśl”.14.

Szkoła shinkankaku musiała się pojawić - napisał Akutagawa - i jak nowe przedsięwzięcie nie jest łatwa. Niewątpliwie, jeśli szukamy nowości, to na pewno znajdziemy ją w shinkankakuha. Ale przecież opowiadanie Supeinu inu no ie (Dom hiszpańskiego psa, 1917) Satō Haruo nie traci świeżości - stwierdził Akutagawa.

Dziennikarz wojenny życia

Shimazaki Tōson (1872-1943) nazwał siebie „dziennikarzem wojennym życia” (jinsei no jūgunkisha). Ostatnio te słowa Hirotsu Kazuo (1891-1968) dodano charakterystyce Masamune Hakuchō. A znaczy to tyle, co neologizm seikatsusha (człowiek [opisujący] życie). W różnym stopniu tacy są wszyscy pisarze.

\footnotetext{
14 R. Akutagawa, Bungeiteki na..., s. 164.
} 


\section{Powieść popularna}

Definiując tsūzoku shōsetsu (lekka, popularna powieść) Akutagawa zwraca uwagę na jej poetyckość i wrażliwość jej czytelników, zwykłych ludzi (zoku). Jest ona przeciwieństwem powieści artystycznej. Akutagawa twierdzi, że różni się od europejskiej powieści popularnej. Nie wyjaśnia sensu „poetyckości” w tego rodzaju powieści ani nie podaje nazwisk pisarzy zaliczanych do tego gatunku, więc nie można stwierdzić, które utwory recenzuje. Możliwe, że ma na myśli sobie współczesnych Kumego Masao (1891-1952) i Kikuchiego Kana (1888-1948) albo również Ozakiego Kōyō (1868-1903) i Tokutomiego Rokę (1868-1927), autorów powieści niezwykle popularnych i cenionych.

\section{Oryginalność}

Akutagawa przyznaje, że nie wie, dlaczego teraz dokonują rozliczenia literatury i sztuki okresów Meiji i Taishō. Wydają dzieła zebrane współczesnej literatury japońskiej, dzieła zebrane literatury Meiji i Taishō. To znów organizują wystawy słynnych dzieł obu okresów. Oglądając i czytając je, zrozumiał, jak trudną rzeczą jest oryginalność - stwierdził Akutagawa (esej trzydziesty ósmy).

Czterdziesty esej pt. Bungeijō no kyokuhoku (Biegun pótnocny literatury) kończy ten cykl rozmyślań, notowanych pospiesznie, jakby ze świadomością szybko zbliżającego się kresu, w nieokreślonym lęku atakującym pisarza w ostatnich miesiącach życia.

Nazbyt literackie: ciąg dalszy

Akutagawa zamierzał jeszcze pisać ciąg dalszy esejów Nazbyt literackie. Nawet rozpoczął nowy cykl pt. Zoku bungeiteki na, amari ni bungeiteki na (Nazbyt literackie [...] Ciag dalszy), w którym opublikowano tylko dziesięć szkiców, to znaczy: Zmarli i żywi, Epoka, Cecha szczególna japońskiej literatury, Anatol France, Naturalizm, Hamsun, Stownictwo, Stowa Cocteau, Gdybym byt królem, Dwaj rudowtosi malarze [Picasso, Matisse].

\section{„Zmarli i żywi”}

Gdy czasopismo „Bunshō Kurabu” zapytało, co zostało w pamięci czytelników z literatury okresu Taishō, Akutagawa również miał zamiar odpowiedzieć, ale stracił okazję. W jego pamięci pozostał tytuł powieści Shisha seisha (Umarli i żywi, 1916) Masamunego Hakuchō. Wydano ją w tym samym miesiącu, co jego opowiadanie Imogayu (Kartoflanka, 1916). Powieść Masamunego zrobiła na nim duże wrażenie, ale nie miała ona dobrej opinii, podobnie jak Imogayu. Podobno nikt z pytanych nie wymienił Shisha seisha w ankiecie. W tym czasie Masamune już nie cieszył się powodzeniem.

\section{„Epoka”}

W ostatnich, bardzo krótkich szkicach, Akutagawa zastanawiał się między innymi nad tym, co by było, gdyby się nie narodził. Na pewno ktoś inny by napisał to, co on. Więc nie ma czym się chwalić. Zanotował jeszcze, że cechą literatury japońskiej jest intymność, co znaczy bliskość czytelnikowi. Ale jego myśli podążają ku takim pisarzom, jak Anatol France, Knut Hamsun, Jean Cocteau i wielcy romantycy niemieccy, Goethe i Heine... 


\section{Polemika między Akutagawą i Tanizakim: Shōsetsu no suji ronsō}

Najbardziej znanym wątkiem Bungeiteki na, amari ni bungeiteki na jest polemika z Tanizakim. Doszło do niej po wypowiedzi Akutagawy, wygłoszonej podczas dyskusji redakcyjnej miesięcznika „Shinchō” w lutym 1927 roku. Wówczas Akutagawa skrytykował Nihon ni okeru Kurippun jiken (Incydent Crippena w Japonii, 1927), twierdząc: „Bardzo wątpię, czy wartość artystyczną ma to, co w powieści nazywa się fabułą (hanashi no suji). Wartości artystycznej powieści nie podnosi ciekawa fabuła"15.

Warto pamiętać, że bohater skrytykowanego opowiadania jest masochistą, który jednak nie potrafi żyć jako niewolnik pięknej aktorki, więc popełnia zbrodnię ${ }^{16}$.

W tym czasie, to znaczy w latach 1926-1927 Tanizaki zastanawiał się nad stylem przyszłych swoich utworów, kierując zainteresowanie w stronę dawnej formy japońskiej opowieści monogatari. Uważał, że powieść współczesna - tak jak starożytna - powinna być formą opowieści fikcyjnej, a nie bezpośrednim opisem rzeczywistości.

„Ostatnio odczuwam dziwną skłonność, a mianowicie pisząc własne utwory i czytając utwory innych autorów, nie interesuję się nimi, jeśli nie ma w nich zmyślenia (uso). Nie mam najmniejszej ochoty ani czytać, ani pisać rzeczy wykorzystujących fakty bezpośrednio, czyli realistycznie” - stwierdza w Jōzetsuroku ${ }^{17}$. Tanizaki oświadczył też, że „współczesnych utworów nie czyta chyba dlatego, że nie ma w nich zmyślenia”. Odrzuca je po przejrzeniu początku i stwierdzeniu, że autor opowiada po prostu o sobie i otoczeniu. Sięga więc raczej do dzieł traktujących o czasach minionych lub o zdarzeniach dalekich od Japonii, na przykład do Daibosatsu tōge lub Heloizy i Abelarda George’a Moore’a czy Pustelni Parmeńskiej Stendhala. Przytacza pogląd Akutagawy pomniejszającego rolę anegdoty w powieści i podkreśla, że jest innego zdania, bowiem w samej fabule kryje się smak łączenia rzeczy w całość, kryje się po prostu urok struktury, czyli piękno architektoniczne. Piękno w literaturze najlepiej ucieleśnia powieść. Nie wolno więc odrzucać tego, co jest przywilejem tego gatunku. A przecież słabością japońskiej powieści jest właśnie brak umiejętności łączenia złożonych zdarzeń w strukturalną całość - twierdzi nie bez podstaw Tanizaki ${ }^{18}$.

Powieść wyrosła ze zwyczaju opowiadania interesujących historii dla dworzan i ludu. Wobec tego takie powieści jak wyznania autorów, pozbawione opowiadań są rzadkie i sprzeczne z koncepcją powieści ${ }^{19}$ głoszoną przez Akutagawę.

Tanizaki już w pierwszym eseju zainteresował czytelników śmiałą pochwałą powieści popularnej pt. Daibosatsu tōge (Przetęcz Wielkiego Bodhisatwy, 1913) autorstwa Nakazato Kaizana, pisarza poczytnego, zwłaszcza w 1925 roku, ale niecenionego przez krytyków.

\footnotetext{
15 Zob. Bungeiteki na, amari bungeiteki na, publikacja w japońskiej wersji Wikipedii [dostęp: 12.07.2016].

16 Zob. S. Chiba, Kaisetsu - mazohisuto no yume (Wyjaśnienia/posłowie - marzenia masochisty), [w:] J. Tanizaki, Jun'íchirō rabirinsu II. Mazohizumu shōsetsushū, red. S. Chiba, Tōkyō 1998, s. 279-288.

17 M. Melanowicz, Tanizaki Jun'ichiro a krąg japońskiej tradycji rodzimej, Warszawa 1976, s. 193.

18 Ibidem.

19 N. Mizuta Lippit, The Plot Controversy between Tanizaki and Akutagawa, [w:] eadem, Reality and Fiction in Modern Japanese Literature, London-Basingstoke 1980, s. 57.
} 
Zainteresowanie tego rodzaju masową powieścią potwierdza również esej Tanizakiego i na temat powieści historycznej Naokiego Sanjūgo (1891-1934) ${ }^{20}$.

Tanizaki skrytykował również powieść realistyczną, a zwłaszcza autobiograficzną shishōsetsu (powieść, opowiadanie o sobie). Stwierdzil, że ostatnio bardziej interesują go wymyślone „kłamstwa” raczej niż opis przeżyć pisarza, a także świadomie skonstruowane historie niż proste opowiadania o życiu. Sam woli pisać odległe od rzeczywistości opowieści, na przykład groteskowe, fantastyczne i historyczne. Odnosząc się do komentarza Akutagawy na temat ostatnich utworów Tanizakiego i wartości artystycznej fabuły w powieści, wyjaśnil, że Akutagawa mylnie ocenia jego pogląd jako osobiste upodobanie złożonych historii, a przecież ceni po prostu strukturę powieści i jej architektoniczne piękno. Upodobanie do dziwnego materiału wynika z artystycznych względów, a nie z obcych idei. I chociaż Akutagawa krytykuje go za to, że jest zafascynowany swoimi wymyślonymi historiami, to jednak należy pamiętać o tym, że interesująca fabuła ułatwia zrozumienie.

Akutagawa nie sądzi jednak, by powieść bez fabuły była najlepsza, jednak to nie fabuła określa jej wartość artystyczną. Stwierdził, iż powieści bez prawdziwej historii (to znaczy fabuły) są bliskie poezji.

Tanizaki odpowiedział w majowym wydaniu „Kaizō”, twierdząc, że nie ma sensu ustalać absolutnego standardu artystycznej wartości powieści czy standardu dla dobrych i złych powieści. Sztuka, podobnie jak historia ludzkości, zmienia się i rozwija, przełamując ustalone kryteria ocen i koncepcji artystycznych. Dodaje, że japońska literatura nadal cierpi z powodu pozostałości złego wpływu naturalizmu, a pisarze jak i czytelnicy łatwe powieści wyznaniowe (tak zwane powieści o sobie) traktują jako głęboką i wysoką sztukę duchową.

W czerwcowym wydaniu „Kaizo” Akutagawa odpowiedział na krytykę Tanizakiego, zwłaszcza odnośnie do wytkniętych sprzeczności. Przyznaje prawie całkowitą rację Tanizakiemu, może z wyjątkiem dwu punktów. Akutagawa nadal utrzymuje, że „czystość” określa artystyczną wartość powieści i że estetyka struktury dotyczy nie tylko długich powieści, lecz także opowiadań.

W innych kwestiach przyjmuje postawę ugodową. Stwierdza, że Tanizaki jest pisarzem, który potrafi dyskutować bez osobistej urazy ${ }^{21}$. Chwali jego styl prozy i kończy esej odwołaniem do Murasaki Shikibu i jej złośliwych komentarzy odnośnie do rywalki Sei Shōnagon. Przypomniał też czas, gdy razem siedzieli w aucie śnieżną nocą i rozmawiali jak przyjaciele o sztuce. W następnym miesiącu Akutagawa popełnił samobójstwo.

\section{Zakończenie}

Kontrowersje między Akutagawą i Tanizakim wzbudziły duże zainteresowanie w kręgach literackich nie tylko ze względu na nazwiska obu znanych i cenionych pisarzy, lecz także z powodu oczekiwania od nich odważnych wypowiedzi zarówno na temat kompozycji i treści powieści, jak i co najmniej sytuacji w życiu kulturalnym kraju. Śmierć Akutagawy

20 J. Tanizaki, Naoki kun no rekishi shōsetsu ni tsuite (O powieści historycznej Naokiego), [w:] Tanizaki Jun'íchirō zenshū (Dzieła zebrane Tanizakiego), t. 22, Tōkyō 1959, s. 89.

21 Zob. też N. Mizuta Lippit, op. cit., s. 58. 
wstrząsnęła środowiskiem literackim, dlatego polemika między nimi nabrała nowego znaczenia. Stała się ważnym wyznacznikiem zachodzących zmian - swego rodzaju progiem między literaturą Taishō i Shōwa - jakkolwiek toczyła się na marginesie życia społecznego i politycznego, wówczas niepozbawionego symptomów niepokojącej przyszłości. Miała charakter po prostu literacki, nazbyt literacki - jak to trafnie określił Akutagawa.

\section{Bibliografia}

Akutagawa Ryūnosuke, Bungeiteki na, amari ni bungeiteki na, [w: ] Akutagawa Ryūnosuke zenshū, t. 10, Tōkyō: Iwanami Shoten, 1955.

—, Kappy, tłum. Mikołaj Melanowicz, Warszawa: PIW, 1963.

—, Tanizaki Jun'ichirō shi, [w:] Akutagawa Ryūnosuke zenshū (Dzieła zebrane Akutagawy), t. 10, Tokio: Iwanami Shoten, 1996, publikacja dostępna na stronie Aozora Bunko, http://www. aozora.gr.jp.

—, Życie pewnego szaleńca, 1. Epoka, tłum. Mikołaj Melanowicz, [w:] idem, Życie szaleńca $i$ inne opowiadania, Warszawa: Wydawnictwo Akademickie Dialog, 1998.

Chiba Shunji, Kaisetsu - mazohisuto no yume (Wyjaśnienia/postowie - marzenia masochisty), [w:] Tanizaki Jun’ichirō, Jun'ichirō rabirinsu II. Mazohizumu shōsetsushū, red. Chiba Shunji, Tōkyō: Chūō Kōronsha, 1998.

Melanowicz Mikołaj, Tanizaki Jun'ichiro a krag japońskiej tradycji rodzimej, Warszawa: Wydawnictwa Uniwersytetu Warszawskiego, 1976.

—, Śnieg i wiśnia - semiotyka tytułu wobec świata przedstawionego w powieści „Sasameyuyki” Jun'ichirō Tanizakiego, [w:] idem, Japońskie narracje. Studia o pisarzach wspótczesnych, Kraków: Wydawnictwo Uniwersytetu Jagiellońskiego, 2004.

Mizuta Lippit Noriko, The Plot Controversy between Tanizaki and Akutagawa, [w:] eadem, Reality and Fiction in Modern Japanese Literature, London-Basingstoke: The Macmillan Press, 1980.

Tanizaki Jun'ichirō, Akutagawa kun to watakushi, [w: Akutagawa Ryūnosuke annai, red. Nakamura Shin'ichirō, Tōkyō: Iwanami Shoten, 1955.

—, Naoki kun no rekishi shōsetsu ni tsuite (O powieści historycznej Naokiego), [w:] Tanizaki Jun'ichirō zenshū (Dzieła zebrane Tanizakiego), t. 22, Tōkyō: Chūō Kōronsha, 1959.

—, Shunkinshō, czyli Rozmyślania nad życiem Wiosennej Harfy, tłum. Mikołaj Melanowicz, [w:] idem, Dwie opowieści o mitości okrutnej, Warszawa: PIW, 1971. 